\title{
EFFECT OF SILICA OBTAINED FROM RICE HUSK ON THE STRUCTURAL AND THERMAL PROPERTIES OF POLYLACTIC ACID/POLYETHYLENE GLYCOL FILMS
}

\author{
*Buğçe AYDIN, Chemical Engineering, Ondokuz Mayıs University, Turkey, bugce.ozogul@omu.edu.tr \\ (iD) https://orcid.org/0000-0001-5104-1484) \\ Feza GEYIKÇİ, Chemical Engineering, Ondokuz Mayıs University, Turkey, fezag@omu.edu.tr \\ (iD) https://orcid.org/0000-0003-4789-1026)
}

Received: 18.08.2019, Accepted: 17.10.2019

Research Article

*Corresponding author DOI: $10.22531 /$ muglajsci.606112

\begin{abstract}
Most of the plastic materials used in the packaging industry are petroleum-based. These plastics do not decompose in soil for many years and they lead to increase $\mathrm{CO}_{2}$ in the atmosphere. Biodegradable polymers derived from renewable resources such as polylactic acid (PLA) are considered as promising alternatives to petroleum-based polymers. Although PLA has attracted attention due to having properties such as biodegradable, environment friendly, and biocompatible, it cannot be used in many applications due to its poor gas barrier properties, low thermal stability, high brittleness, and cost. In this study, in the first step silica was obtained from the rice husk. The obtained silica (5,10 and 20\%) were added to PLA solutions containing 20\% polyethylene glycol (PEG) and the composite films were prepared using solvent casting method. The thermal and structural properties of the composite films were determined by Fourier Transform Infrared Spectroscopy (FTIR), Scanning Electron Microscope (SEM), Thermogravimetric Analysis (TGA), Differential Scanning Calorimetry (DSC) and Water Absorption Capacity Test. According to results of analysis, the addition of silica to the PLA-PEG films improved the thermal stability and increased the water absorption capacities of films.

Keywords: Polylactic acid, Rice husk, Silica, Biodegradable polymer, Composite material

\section{PİRINÇ KABUĞUNDAN ELDE EDİLEN SİLIKANIN POLİLAKTİK ÖZELLİKLERİNE ETKİSI} ASİT/POLİETİLEN GLİKOL FİLMLERININ YAPISAL VE TERMAL
\end{abstract}

\section{Özet}

Ambalaj sektöründe kullanılan plastik malzemelerin çoğu petrol kökenlidir. Bu tür malzemeler doğada uzun yıllar çözünmeyip atmosferdeki $\mathrm{CO}_{2}$ 'in artmasına neden olur. Yenilenebilir kaynaklardan elde edilen polilaktik asit (PLA) benzeri biyobozunur polimerler petrol kökenli polimerlere alternatif olarak görülmektedir. PLA çevre dostu, biyobozunur ve biyouyumlu olması gibi birçok avantaja sahip olmasına rağmen düşük gaz bariyer özellikleri, termal dayanımı, kırılgan ve maliyetli olması birçok uygulamada kullanımını sınırlamaktadır. Bu çalışmada ilk olarak atık olarak görülen pirinç kabuğundan silika elde edilmiştir. Farklı katkı yüzdelerinde (\%5, 10 ve 20) silika \%20 polietilen glikol (PEG) içeren PLA çözeltilerine eklenmiş ve kompozit filmler çözücü döküm yöntemi ile hazırlanmıştır. Filmlerin termal ve yapısal özellikleri Fourier Dönüşümlü İfrared Spektroskopi (FT-IR), Taramalı Elektron Mikroskobu (SEM), Termogravimetrik Analiz (TGA), Diferansiyel Taramalı Kalorimetre (DSC) ve Su Absorpsiyon Kapasitesi Testi ile belirlenmiştir. Analiz sonuçlarına göre, silikanın PLA-PEG filmlerinin termal dayanımını iyileștirdiği ve su tutma kapasitelerini artırdığı görülmüştür.

Anahtar Kelimeler: Polilaktik asit, Pirinç kabuğu, Silika, Biyobozunur polimer, Kompozit malzeme

Cite

Aydın, B., Geyikçi, F., (2019). “Effect of Silica Obtained from Rice Husk on the Structural and Thermal Properties of Polylactic Acid/Polyethylene Glycol Films", Mugla Journal of Science and Technology, 5(2), 91-96.

\section{Introduction}

Most of the plastic materials used in the packaging industry are petroleum-based. These plastics such as polyethylene (PE), polystyrene (PS) and, polyethylene terephthalate (PET) do not decompose in soil for many years. They lead to increase environmental pollution and
$\mathrm{CO}_{2}$ in the atmosphere. There have been various approaches to eliminate environmental pollution caused by plastics. Today, the best approach is seen as using biodegradable polymers [1].

Among the biodegradable polymers, polylactic acid (PLA) has attracted attention due to having properties such as biodegradable, environmental-friendly, 
biocompatible, easily processable, transparent, high modulus and strength. Although PLA has these advantages, it cannot be used in many applications due to its poor gas barrier properties, low thermal stability, fragile and cost [2,3]. The physical, thermal or mechanical properties of PLA can be improved by several methods, such as adding of plasticizers [4-6], using reinforcements [7-10] or polymer blends [11-13]. Natural fillers as reinforcements to PLA have advantages such as low cost, renewability and biodegradability. Therefore, biodegradable polymer composites reinforced with natural fillers appear to be an alternative material to petroleum-based materials.

Rice husk is an agricultural waste obtained by rice production process. It is cheap, biodegradable and has been abundance in the world. In developed countries, such products are not seen as waste but as a new source. Therefore, such materials can be used for environmental protection and the design of new materials. Ash content of rice husk mainly consists of silica (approximately $94 \%$ of silica) [14]. Since rice husk is a renewable, biodegradable, low cost, easily available resource, it is seen as a good alternative to conventional reinforcements such as carbon black, commercial silica and clay to reduce the cost of production and improve the properties of biodegradable polymer materials [15]. In this study, PLAPEG-silica composites were prepared using silica obtained from waste rice husk and structural and thermal properties of composite films were investigated in detail.

\section{Material and Methods}

\subsection{Material and Preparation Techniques}

PLA2003D (1.24 g/cm³ 3 125,780 g/mole) was purchased from NatureWorks. PEG600 (1.13 g/ $\mathrm{cm}^{3}, \quad 570-630$ $\mathrm{g} /$ mole) by Merck, Chloroform $\left(1.49 \mathrm{~g} / \mathrm{cm}^{3}\right)$ and Hydrochloric acid $\left(1.18 \mathrm{~g} / \mathrm{cm}^{3}\right)$ by Sigma-Aldrich were supplied. Rice husk was procured from Bafra, Samsun.

Silica was prepared from rice husk based on a procedure reported previously [15]. The rice husks were purified with pure water. $10 \mathrm{~g}$ of rice husks in $0.4 \mathrm{M} 100 \mathrm{ml} \mathrm{HCl}$ solution was boiled at $105{ }^{\circ} \mathrm{C}$ for 45 minutes and they were washed with water to remove acid and then dried in an oven $\left(110^{\circ} \mathrm{C}\right)$ for 4 hours. Additionally, rice husks were burned at $600{ }^{\circ} \mathrm{C}$ in the muffle furnace and silica was obtained after 6 hours. The obtained silica was ground in a coffee grinder and sieved to a particle size of less than $45 \mu \mathrm{m}$. Figure 1 shows the rice husk and obtained rice husk ash in the study.

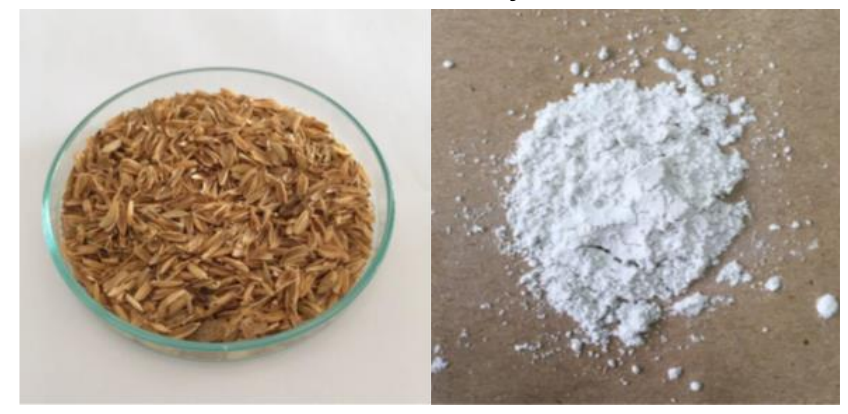

(a)

(b)

Figure 1. (a) Rice husk; (b) Rice husk ash.

In this study, PLAPEG-silica films with 5, 10 and 20 weight percent (wt.\%) compositions (from now onward referred to as PLAPEGS5, PLAPEGS10 and PLAPEGS20, respectively) were prepared using solvent casting method. Before film preparation, PLA granules were dried at $60{ }^{\circ} \mathrm{C}$ for $24 \mathrm{~h}$. $5 \mathrm{wt}$. \% of PLA solution in chloroform was prepared with the help of magnetic stirrer. PEG (20 wt.\%) was dissolved into PLA solutions. The desired amount of silica (5, 10 and $20 \mathrm{wt} . \%)$ was added to polymer blend. The mixture was stirred in magnetic and ultrasonic stirrer for 1 day and cast onto petri dish. It was allowed to dry in an oven at $40{ }^{\circ} \mathrm{C}$ for 3 days. The method is briefly summarized in the Figure 2. The thermal and structural properties of the prepared composite films were determined by SEM (Scanning Electron Microscope), FT-IR (Fourier Transform Infrared Spectroscopy), TGA (Thermogravimetric Analysis). Water absorption capacity of films were also investigated.

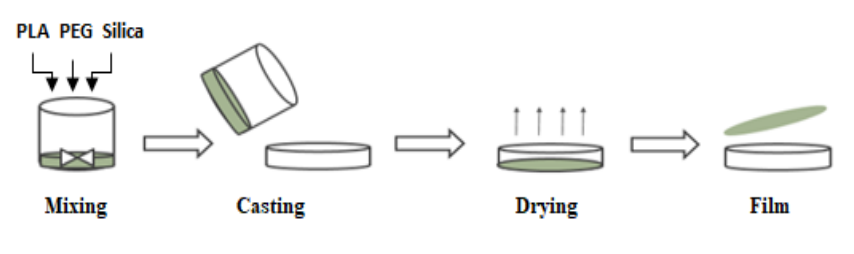

Figure 2. Solvent casting method.

\subsection{Characterization}

Fourier Transform Infrared Spectrometer (FT-IR/ATR, Perkin Elmer-2000FTIR) was used to investigate interaction between polymer matrix and reinforcement. For analysis, 5-10 mg of samples placed in the appliance. The spectra of films were recorded between in the wavenumber range of $650-4000 \mathrm{~cm}^{-1}$.

Thermal behaviour of the samples was determined by using TGA (TA, SDTQ600). Approximately 5-10 mg of sample was placed in the sample cup and kept at a heating rate of $10{ }^{\circ} \mathrm{C} / \mathrm{min}$ under $\mathrm{N}_{2}$ flow of $50 \mathrm{ml} / \mathrm{min}$ from room temperature to $600{ }^{\circ} \mathrm{C}$.

DSC analysis (TA, DSCQ2000) of the samples were determined under heating speed of $10{ }^{\circ} \mathrm{C} / \mathrm{min}$ in the range of $25-200{ }^{\circ} \mathrm{C}$. The samples were first heated from room temperature to $200{ }^{\circ} \mathrm{C}$ under a heating rate of 10 ${ }^{\circ} \mathrm{C} / \mathrm{min}$, cooled to $25^{\circ} \mathrm{C}$ at the same heating rate and then reheated to $200{ }^{\circ} \mathrm{C}$.

Thermal properties of the films such as crystallization temperature $\left(\mathrm{T}_{\mathrm{c}}\right)$, melting point temperature $\left(\mathrm{T}_{\mathrm{m}}\right)$, crystallization enthalpy $\left(\Delta \mathrm{H}_{\mathrm{c}}\right)$ and melting enthalpy $\left(\Delta \mathrm{H}_{\mathrm{m}}\right)$ were determined by DSC analysis. The degree of crystallinity $\left(\% \mathrm{X}_{\mathrm{c}}\right)$ was calculated using the following equation.

$$
\% X c=\frac{\Delta H_{m}}{f x \Delta H_{m}^{0}} \times 100
$$

$\Delta \mathrm{H}_{\mathrm{m}}=$ Melting enthalpy $(\mathrm{J} / \mathrm{g})$ 
$\Delta \mathrm{H}_{\mathrm{m}}{ }^{0}=$ Theoretical melting enthalpy of $100 \%$ crystalline PLA (93.7 J/g) [16]

$\mathrm{f}=$ Weight fraction of PLA

Surface characterization of polymer composite films and silica were determined by Scanning Electron Microscopy (SEM, Jeol, JSM-7001F). Approximately $5 \mathrm{mg}$ of samples were coated with gold and palladium before SEM analysis.

To determine the water absorption capacity of the sample, the film samples were cut to $10 \mathrm{~mm} \times 10 \mathrm{~mm}$ dimensions and dried $\left(105{ }^{\circ} \mathrm{C}\right)$ until constant weight $\left(\mathrm{W}_{0}\right)$. The sample was kept in the closed containers containing pure water in a shaking water bath at $30{ }^{\circ} \mathrm{C}$ for 24 hours. At the end of the period, the sample was dried with a cloth and weighed $\left(\mathrm{W}_{1}\right)$. The water absorption capacity of the film was determined by using the mass difference in the sample. Measurements were completed by taking at least 3 samples for each film.

$$
\begin{aligned}
& \% \text { Water Absorption Capacity } \\
& \qquad=\frac{W_{1}-W_{0}}{W_{0}} \times 100
\end{aligned}
$$

\section{Results and Discussion}

\subsection{Analysis Result of Silica}

The functional groups in silica obtained from rice husk were determined by FT-IR. As seen in Figure 3, stretching and bending vibration of $\mathrm{Si}-\mathrm{O}-\mathrm{Si}$ is determined at the wavenumber of 1047 and $798 \mathrm{~cm}^{-1}$ [17].

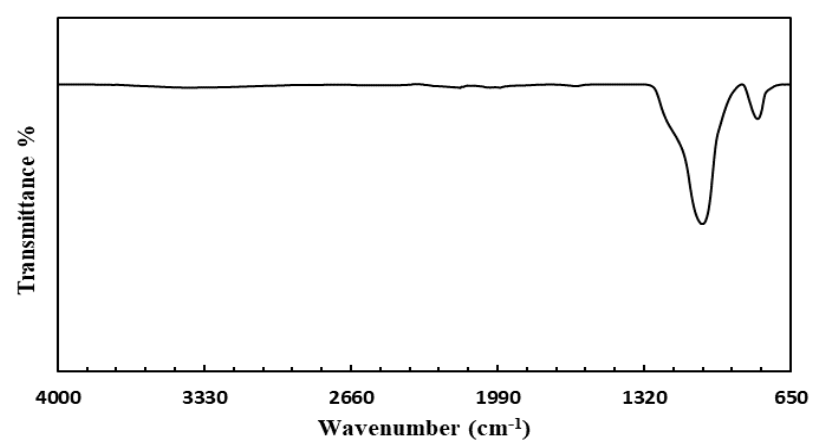

Figure 3. FT-IR spectra of silica obtained from rice husk.

SEM images of silica are given in Figure 4. It is seen that structure has an irregular shape and tends to aggregate [18]. The particle size of silica is found to be less than 45 $\mu \mathrm{m}$. The elements in the structure were determined by Energy Dispersive Spectroscopy (EDS) analysis and it was found that silica contains 62.85 oxygen and 37.15 silicon (wt.\%). The results of the analysis are shown in Table 1.

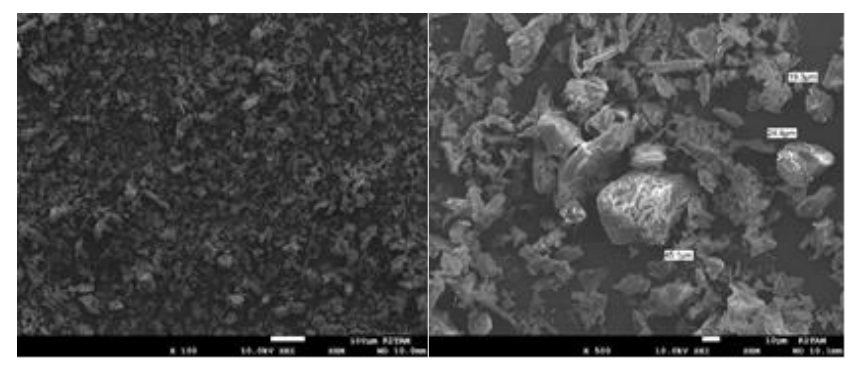

Figure 4. SEM images of silica obtained from rice husk. Table 1. SEM-EDS results of silica obtained from rice husk.

\begin{tabular}{cc}
\hline Element & \% \\
\hline 0 & 62.85 \\
Si & 37.15 \\
Total & 100 \\
\hline
\end{tabular}

\subsection{Analysis Result of Composite Films}

As depicted in Figure 5, the silicon-derived peak at 800 $\mathrm{cm}^{-1}$ is apparent. It was determined that the spectra of the films including silica have peaks similar to the peaks in the spectrum of the PLAPEG film. This shows that the structure contains the same groups that no new bond formation occurs and there is no strong chemical interaction.

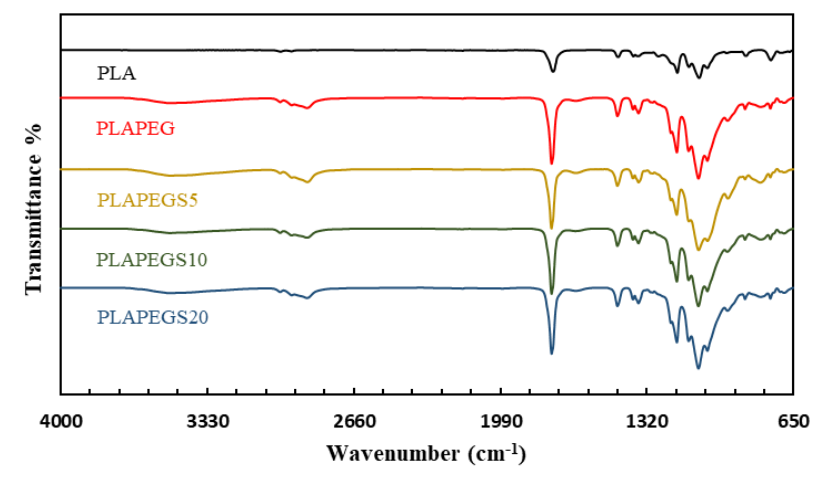

Figure 5. FT-IR spectra of composite films.

TGA results of composite films are given in Figure 6 and Table 2. When the values of pure PLA are considered, it is seen that PLA is completely degraded at the end of 600 ${ }^{\circ} \mathrm{C}$ and has the best thermal stability. Decomposition of PLA occurred between $275^{\circ} \mathrm{C}$ and $380{ }^{\circ} \mathrm{C}$. The use of PEG increases the mobility of the polymer chains and improves the flexibility of PLA. According to curves, PEG leads to decrease thermal stability of PLA $[16,19]$. With the addition of PEG, the thermal decomposition temperature decreased from $280{ }^{\circ} \mathrm{C}$ to $224{ }^{\circ} \mathrm{C}$ and the temperature at which $50 \%$ mass loss occurred decreased from $351{ }^{\circ} \mathrm{C}$ to $298{ }^{\circ} \mathrm{C}$. The final decomposition temperature of PLA increased from $378^{\circ} \mathrm{C}$ to $415^{\circ} \mathrm{C}$ in the presence of PEG [15].

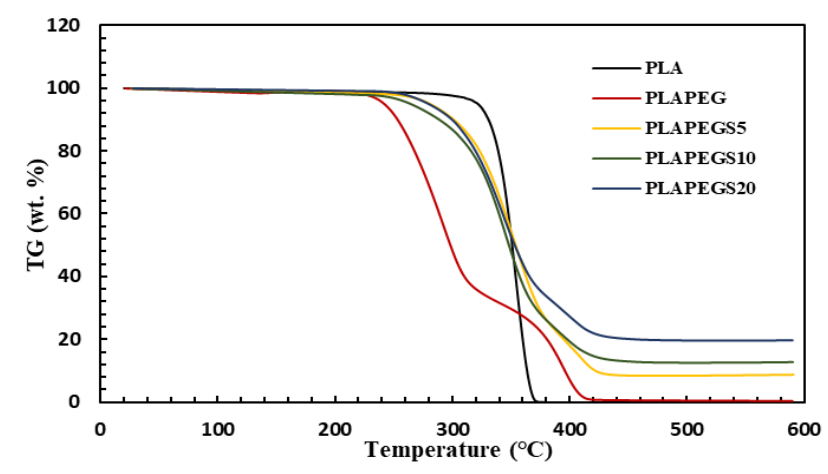

Figure 6. TGA curves of films. 
Table 2. TGA results of composite films.

\begin{tabular}{llllll}
\hline Samples & $\begin{array}{l}\mathrm{T}_{\mathrm{d}} \\
\left({ }^{\circ} \mathrm{C}\right)\end{array}$ & $\begin{array}{l}\mathrm{T}_{\% 5} \\
\left({ }^{\circ} \mathrm{C}\right)\end{array}$ & $\begin{array}{l}\mathrm{T}_{\% 10} \\
\left({ }^{\circ} \mathrm{C}\right)\end{array}$ & $\begin{array}{l}\mathrm{T}_{\% 50} \\
\left({ }^{\circ} \mathrm{C}\right)\end{array}$ & $\begin{array}{l}\mathrm{T}_{\mathrm{f}} \\
\left({ }^{\circ} \mathrm{C}\right)\end{array}$ \\
\hline PLA & 280 & 322 & 331 & 351 & 378 \\
PLAPEG & 224 & 242 & 253 & 298 & 415 \\
PLAPEGS5 & 228 & 281 & 301 & 354 & 456 \\
PLAPEGS10 & 229 & 279 & 300 & 353 & 465 \\
PLAPEGS20 & 235 & 264 & 289 & 348 & 472 \\
\hline
\end{tabular}

By using of silica, it became difficult to remove volatile components from the structure and the thermal decomposition temperature began shifted to higher temperatures. The thermal stability of all composites is higher than PLAPEG film [17]. The results showed that silica could improve the thermal degradation temperature of PLA-PEG blend.

DSC analysis results of the films are shown in Table $3 . \mathrm{T}_{\mathrm{m}}$ and $\mathrm{T}_{\mathrm{c}}$ values of pure PLA were determined as $149.48{ }^{\circ} \mathrm{C}$ and $123.56{ }^{\circ} \mathrm{C}$, respectively. When the plasticizer is added to the PLA, the interaction between the molecular chains decreases and the free volume of the PLA increases. This effect can be determined by the decrease in the $\mathrm{T}_{g}$ and $\mathrm{T}_{c}$ of the polymer. The $\mathrm{T}_{\mathrm{m}}$ and $\mathrm{T}_{\mathrm{c}}$ of the PLAPEG film were $147.14{ }^{\circ} \mathrm{C}$ and $75.33{ }^{\circ} \mathrm{C}$, respectively. The results show that the polymers are compatible and miscible with each other. This attribution was supported by SEM images of the films. A decrease of approximately $2-3{ }^{\circ} \mathrm{C}$ in the melting point indicates that PEG does not affect the melting point of PLA. \% $\mathrm{X}_{\mathrm{c}}$ of PLAPEG film increased from $17.38 \%$ to $34.47 \%$ with the addition of PEG in accordance with the literature [16]. This result shows that plasticizer increases chain movement of PLA and gains flexibility to PLA [20].

Table 3. DSC results of composite films.

\begin{tabular}{lccccc}
\hline Samples & $\begin{array}{c}\mathrm{T}_{\mathrm{c}} \\
\left({ }^{\circ} \mathrm{C}\right)\end{array}$ & $\begin{array}{c}\Delta \mathrm{H}_{\mathrm{c}} \\
(\mathrm{J} / \mathrm{g})\end{array}$ & $\begin{array}{c}\mathrm{T}_{\mathrm{m}} \\
\left({ }^{\circ} \mathrm{C}\right)\end{array}$ & $\begin{array}{c}\Delta \mathrm{H}_{\mathrm{m}} \\
(\mathrm{J} / \mathrm{g})\end{array}$ & $\begin{array}{c}\mathrm{X}_{\mathrm{c}} \\
(\%)\end{array}$ \\
\hline PLA & 123.56 & 16.75 & 149.48 & 16.27 & 17.38 \\
PLAPEG & 75.33 & 16.04 & 147.14 & 25.81 & 34.47 \\
PLAPEGS5 & 72.58 & 14.84 & 146.58 & 25.41 & 35.72 \\
PLAPEGS10 & 79.19 & 18.55 & 147.18 & 19.39 & 28.77 \\
PLAPEGS20 & 84.83 & 16.15 & 146.87 & 16.55 & 27.63 \\
\hline
\end{tabular}

The fact that the crystallization temperature value of composite films is lower than pure PLA is interpreted as the silica increases the crystallization rate of the polymer. The fillers act as a nucleating agent for crystallization and causes decrease in the crystallization temperature [21]. When $5 \%$ of silica was added to the PEG-including films, the $\mathrm{T}_{c}$ value of the films decreased from 75.33 to $72.58{ }^{\circ} \mathrm{C}$, respectively. The decreasing \%Xc value of the film containing $10 \%$ and $20 \%$ silica may be due to the voids in the structure with increasing filler amounts [10]. Crystals are more easily formed by the nucleation effect of particles when the amounts of filler are low. As the amount of filler increases, the crystallization behaviour of PLA may decreases due to aggregation [22].

SEM analysis was performed to determine the morphological structure of polymer films. As seen from Figure 7, the pure PLA which forms the matrix in composite films has a smooth and homogeneous surface. This smooth structure shows the fragility of PLA [20]. In the SEM image of the PLAPEG film, a homogeneous structure is formed and the mixture has a smooth surface. It is seen that the polymers in the mixture are compatible with each other [23].

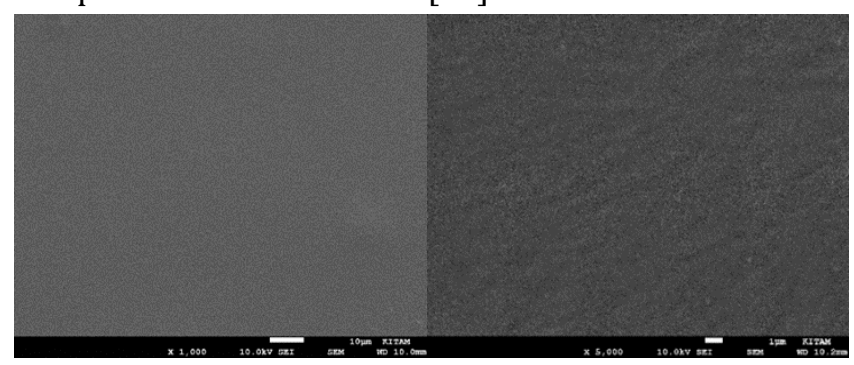

(a)

(b)

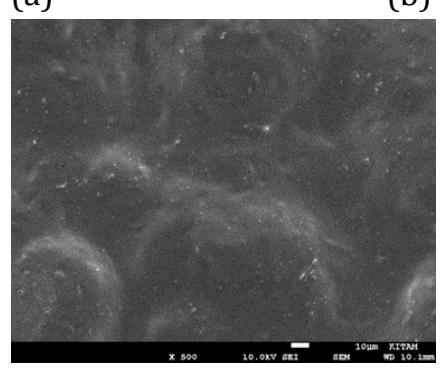

(c)

Figure 7. SEM images of composite films a) neat PLA b) PLAPEG c) PLAPEG20.

The distribution of fillers in the polymer matrix effects the physical properties of the material. The strong interaction between matrix and silica improves the thermal, mechanical and structural properties of the material [24].

In the SEM image of the silica-doped film, gaps and irregular cracks occur in the structure resulting from weak adhesion forces and stress between the matrix and the reinforcing element [20]. It is thought that the cavities on the surface are caused by chloroform which is withdraw from the structure. The silica particles in the structure were identified as white dots. Due to the small particle size of the fillers, they were embedded in the matrix and distributed homogeneously. The particles were far away from each other and there were no remarkable aggregates.

Water acts as a plasticizer in many materials. It leads to size change and reduces the mechanical properties. Hydrophilic additives swell when combined with water. Thus, composite films absorb more water and improve the biodegradability behaviour of the material [25].

Figure 8 shows the water absorption capacities of the composite films with different silica content. PLA is a hydrophobic polymer. In this study, water absorption capacity of PLA was determined as $0 \%$ as given in the literature [26]. Considering the amount of water 
absorbed by the films, the water absorption capacity increased due to the hygroscopic nature of the fillers. As the filler content increased from $10 \%$ to $20 \%$, water absorption capacities of silica-containing film increased from $9 \%$ to $21 \%$. These results showed that 1 gram of film containing $10 \%$ silica and $20 \%$ silica can absorb 0.09 $\mathrm{ml}$ and $0.21 \mathrm{ml}$ of water, respectively.

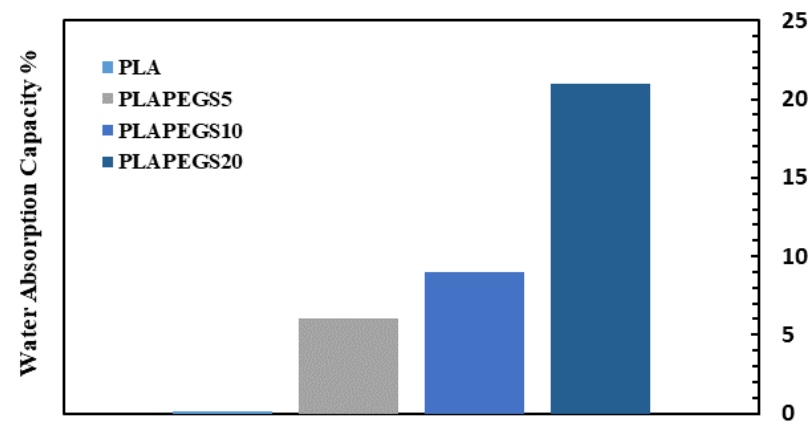

Figure 8. Water absorption capacities of films.

\section{Conclusion}

The aim of this study was to improve the thermal and structural properties of pure PLA. In order to obtain flexible PLA, a polymer mixture was formed with PEG. The degree of crystallinity of the PLAPEG film increased from $17.38 \%$ to $34.47 \%$. This shows that PLA has increased chain movement and gained flexibility in the presence of PEG. It has been seen that the water absorption capacity of PLA film increased with the addition of silica. The rate of degradation of biodegradable polymers in a suitable compost environment depends on the water absorption ability. PLA can be completely degraded in 2 years on average. Silica-doped PLA can be degraded in a shorter time in comparison with neat PLA. Silica also improved the thermal stability of the films which was reduced by plasticizing effect. All composites were found to have better thermal stability than PLAPEG film.

\section{Acknowledgment}

This study was supported by Scientific Research Projects of Ondokuz Mayıs University (Project Number: PYO.MUH.1904.16.008).

\section{References}

[1] Niu, X., Liu, Y., Song, Y., Han, J., and Pan, H., "Rosin modified cellulose nanofiber as a reinforcing and coantimicrobial agents in polylactic acid/chitosan composite film for food packaging", Carbohydrate Polymers, vol.183, pp. 102-109, 2018.

[2] Ebnesajjad S., "Handbook of Biopolymers and Biodegradable Plastics: Properties, Processing and Applications", Elsevier Science, USA, 2013.

[3] Murariu, M., and Dubois, P., "PLA composites: From production to properties". Advanced Drug Delivery reviews, vol.107, pp. 17-46, 2016.

[4] Carbonell-Verdu, A., Garcia-Garcia, D., Dominici, F., Torre, L., Sanchez-Nacher, L., and Balart, R., "PLA films with improved flexibility properties by using maleinized cottonseed oil", European Polymer Journal, vol. 91, pp. 248-259, 2017.

[5] Elsawy, M., JdC, C., and Sanporean, C. G., "Investigation of jojoba oil-wax as a plasticizer for poly (lactic acid)", Optoelectron Adv. Mater., vol. 8(1-2), pp. 109-14, 2014.

[6] Prempeh, N., Li, J., Liu, D., Das, K., Maiti, S., and Zhang, Y., "Plasticizing effects of epoxidized sun flower oil on biodegradable polylactide films: a comparative study", Polymer Science Series A, vol. 56, no.6, pp. 856-863, 2014.

[7] Hao, Y. H., Huang, Z., Wang, J. W., Yang, X. Y., Fan, X. Y., Li, Y. I., and Peng, Y. W., "Improved thermal stability of poly (L-lactide) with the incorporation of zeolite ZSM-5", Polymer Testing, vol. 49, pp. 46-56, 2016.

[8] Ho, M. P., Lau, K. T., Wang, H., and Hui, D., "Improvement on the properties of polylactic acid (PLA) using bamboo charcoal particles", Composites Part B: Engineering, vol. 81, pp.14-25, 2016.

[9] Yang, W., Fortunati, E., Dominici, F., Kenny, J. M., and Puglia, D., "Effect of processing conditions and lignin content on thermal, mechanical and degradative behavior of lignin nanoparticles/polylactic (acid) bionanocomposites prepared by melt extrusion and solvent casting", European Polymer Journal, vol. 71, pp. 126-139, 2015.

[10] Yamoum, C., and Magaraphan, R., "Effect of peanut shell content on mechanical, thermal, and biodegradable properties of peanut shell/polylactic acid biocomposites", Polymer Composites, vol. 38, no. 4, pp. 682-690, 2017.

[11] Wang, L. F., Rhim, J. W., and Hong, S. I., "Preparation of poly (lactide)/poly (butylene adipate-coterephthalate) blend films using a solvent casting method and their food packaging application", LWT-Food Science and Technology, vol. 68, pp. 454-461, 2016.

[12] Weng, Y. X., Jin, Y. J., Meng, Q. Y., Wang, L., Zhang, M., and Wang, Y. Z., "Biodegradation behavior of poly (butylene adipate-co-terephthalate) (PBAT), poly (lactic acid) (PLA), and their blend under soil conditions", Polymer Testing, vol. 32, no.5, pp. 918-926, 2013.

[13] Matta, A. K., Rao, R. U., Suman, K. N. S., and Rambabu, V., "Preparation and characterization of biodegradable PLA/PCL polymeric blends", Procedia Materials Science, vol. 6, pp. 1266-1270, 2014.

[14] Yalcin, N., and Sevinc, V., "Studies on silica obtained from rice husk", Ceramics International, vol. 27, no. 2, pp. 219-224, 2001.

[15] Ahmed, K., Nizami, S. S., and Riza, N. Z., "Reinforcement of natural rubber hybrid composites based on marble sludge/Silica and marble sludge/rice husk derived silica", Journal of Advanced Research, vol. 5, no. 2, pp. 165-173, 2014.

[16] Zhang, J., Wang, S., Zhao, D., Zhang, Y., Pang, W., Zhang, B., and Li, Q., "Improved processability and performance of biomedical devices with poly (lactic acid)/poly (ethylene glycol) blends", Journal of Applied Polymer Science, vol. 134, no. 33, pp. 45194, 2017. 
[17] Battegazzore, D., Bocchini, S., Alongi, J., and Frache, A., "Rice husk as bio-source of silica: preparation and characterization of PLA-silica bio-composites", RSC Advances, vol. 4, no. 97, pp. 54703-54712, 2014.

[18] Ayswarya, E. P., Francis, K. V., Renju, V. S., and Thachil, E. T., "Rice husk ash-A valuable reinforcement for high density polyethylene", Materials \& Design, vol. 41, pp. 1-7, 2012.

[19] Chieng, B., Ibrahim, N., Yunus, W., and Hussein, M., "Poly (lactic acid)/poly (ethylene glycol) polymer nanocomposites: effects of graphene nanoplatelets", Polymers, vol. 6, no. 1, pp. 93-104, 2014.

[20] Mohapatra, A. K., Mohanty, S., and Nayak, S. K., "Properties and characterization of biodegradable poly (lactic acid) (PLA)/poly (ethylene glycol) (PEG) and PLA/PEG/organoclay: A study of crystallization kinetics, rheology, and compostability", Journal of Thermoplastic Composite Materials, vol. 29, no. 4, pp. 443-463, 2016.
[21] Ray, S. S., Yamada, K., Ogami, A., Okamoto, M., and Ueda, K., "New polylactide/layered silicate nanocomposite: nanoscale control over multiple properties", Macromolecular Rapid Communications, vol. 23, no. 16, pp. 943-947, 2002.

[22] Wen, X., Lin, Y., Han, C., Zhang, K., Ran, X., Li, Y., and Dong, L., "Thermomechanical and optical properties of biodegradable poly ( $\mathrm{L}$ - lactide)/silica nanocomposites by melt compounding", Journal of Applied Polymer Science, vol. 114, no. 6, pp. 3379-3388, 2009.

[23] Darie - Niţă, R. N., Vasile, C., Irimia, A., Lipşa, R., and Râpă, M., "Evaluation of some eco - friendly plasticizers for PLA films processing", Journal of Applied Polymer Science, vol. 133, no. 13, 2006.

[24] Li, Y., Han, C., Bian, J., Han, L., Dong, L., and Gao, G. "Rheology and biodegradation of polylactide/silica nanocomposites", Polymer Composites, vol. 33, no. 10, pp. 1719-1727, 2012.

[25] Toro, P., Quijada, R., Murillo, O., and Yazdani Pedram, M., "Study of the morphology and mechanical properties of polypropylene composites with silica or rice - husk", Polymer International, vol. 54, no. 4, pp. 730$734,2005$.

[26] Rhim, J. W., Mohanty, A. K., Singh, S. P., and Ng, P. K., "Effect of the processing methods on the performance of polylactide films: Thermocompression versus solvent casting", Journal of Applied Polymer Science, vol. 101, no. 6, pp. 3736-3742, 2006. 